\title{
Designing for Safety: Implications of a Fifteen Year Review of Swallowed and Aspirated Dentures
}

\author{
Samuel J. W. Kent ${ }^{1}$, James Mackie ${ }^{1}$, Tatiana V. Macfarlane ${ }^{1}$ \\ ${ }^{1}$ The University of Aberdeen School of Dentistry, University of Aberdeen, Scotland, United Kingdome.
}

\section{Corresponding Author:}

Samuel John Wilfrid Kent

The University of Aberdeen Dental School

University of Aberdeen

Foresterhill Campus, AB25 2ZN, Westburn Road, Aberdeen

United Kingdome

Phone: $+44(0) 1224551901$

Fax: +44 (0)1224 272576

E-mail: s.kent.02@aberdeen.ac.uk

\begin{abstract}
Objectives: Dentures are worn by around $20 \%$ of the population, yet if they become displaced they may enter the gastrointestinal or respiratory system, sometimes with grave consequences. The aim of this study was to review recent published literature in order to identify the epidemiology of patients and characteristics of swallowed and aspirated dental prostheses, and propose strategies to minimise these risks.

Material and Methods: A fifteen year retrospective of published case series and case reports was carried out. Photographs, radiographs and descriptions of the dental prostheses were gathered, as well as the patient's presenting complaint, the anatomical site where the denture was caught and the procedure required to remove the denture.

Results: Ninety one separate events of swallowed or aspirated dentures were identified from 83 case reports and series from 28 countries. Average age was 55 years, and these were $74 \%$ male. Photographs were retrieved for 49 of these dentures. Clasps were present in 25 of the dentures. There was no significant difference between clasped and unclasped dentures for perforation rates, need for open surgery and spontaneously passed dentures.

Conclusions: We discuss the implications of this study regarding denture designs, specifically the importance of using a radiopaque acrylic, using clasps when required even if there is a risk of aspiration, advising patients to return if a denture is loose or damaged, and finally that all patients who wear a denture are at risk of aspiration and swallowing events, and associated morbidity and mortality.
\end{abstract}

Keywords: deglutition; dentures; denture design; dental prosthesis design; respiratory aspiration.

\author{
Accepted for publication: 9 June 2016 \\ To cite this article: \\ Kent SJW, Mackie J, Macfarlane TV. \\ Designing for Safety: Implications of a Fifteen Year Review of Swallowed and Aspirated Dentures \\ J Oral Maxillofac Res 2016;7(2):e3 \\ URL: http://www.ejomr.org/JOMR/archives/2016/2/e3/v7n2e3.pdf \\ doi: $10.5037 /$ jomr.2016.7203
}




\section{INTRODUCTION}

Dentures are worn by around $20 \%$ of the population, yet if displaced they may enter the gastrointestinal or respiratory system, sometimes with grave consequences [1]. Further understanding of the epidemiology, and possible consequences of such events could lead to more informed prescription of appropriate denture design, and hence reduce these risks.

Tooth replacement is carried out to improve masticatory efficiency and aesthetics, reduce overeruption and drifting of unopposed teeth, and to restore phonetics [2]. Prosthodontics may be of the upper or lower jaw, may be removable or fixed, and may be made out of plastic, metal, ceramic or a combination. An appropriate prescription for tooth replacement takes into account many factors including patient's aesthetic requirements, amount of remaining alveolar bone, dental health of remaining teeth, strength of the gag reflex, and financial cost [2]. Assessment of a patient's risk of aspirating or swallowing a particular denture is also an important part of this process.

Once a denture passes posteriorly into the oropharynx, or down into the hypopharynx, it may either continue into the aerodigestive system or be expelled back to the oral cavity by the usual gag reflex. Any factor which inhibits the gag reflex could be reasonably considered to increase the risks of aspiration or swallowing of a denture. Such factors may include neuromuscular disorders such as stroke, multiple sclerosis or Parkinson's disease. From the hypopharynx, the denture may pass into the larynx and then into the respiratory system, or it may enter the oesophagus. In the larynx, the vocal cords may prevent further ingress, or the denture may pass inferiorly to the carina. From there, the more direct path is into the right bronchus, and then, depending on size, into the bronchioles.

In the oesophagus there are four well documented sites where foreign bodies may lodge: a) at the level of the cricoid cartilage, b) where the oesophagus is compressed by the aortic arch, c) compressed by the left main bronchus, d) at the lower oesophageal sphincter [3]. The stomach presents few obstructions to the foreign body, though the small bowel progressively decreases in diameter up until the ileocecal valve. Other obstructions may be caused by malignant lesions in the large bowel [4].

Different designs of dental prostheses may lodge in different areas, or may pass through the gastrointestinal tract altogether. Dentures with clasps may be more likely to become 'hooked' on the mucosa of the aerodigestive tract, whilst small fixed dentures may pass out in stool.

Different designs may also require varying surgical strategies for removal whilst short fixed dentures may be safely monitored as they traverse the intestines, larger dentures may require endoscopic removal, and those which have become attached to the mucosa may require open surgery. Dentures made entirely of acrylic present a particular challenge as they cannot be easily identified on plain X-rays, and therefore a CT or MRI scan may be necessary to determine their position. There is clear potential for morbidity and even mortality from a swallowed or aspirated denture. Therefore it is important to minimise the risk of aspirating or swallowing dentures, and mitigate the potential damage. We review recent published literature in order to identify the epidemiology of patients and characteristics of swallowed and aspirated dentures, and propose strategies to minimise these risks.

\section{MATERIAL AND METHODS Protocol and registration}

A systematic review was carried out using the PRISMA 2009 guidelines (www.prisma-statement. org/PRISMAStatement/).

The methods were specified in advance. The review was not registered on any database.

\section{Focus question}

The following focus question was developed according to the population, intervention, comparison and outcome (PICO) study design: what are the common design features, morbidities, therapeutic strategies and epidemiology of swallowed and aspirated dentures reported in case studies?

\section{Information sources and search}

The authors searched Embase and Medline, with date limits $1^{\text {st }}$ January 2000 to $31^{\text {st }}$ December 2015 inclusive, using the MeSH terms 'denture', 'swallow' and 'aspirate' in various combinations. Primary search strategy was 'denture' AND ('swallowed' OR 'aspirated'). Hand searching of references was also carried out for each of the studies.

\section{Selection of studies}

Studies were limited to English language and Human, 
and review articles were excluded. This date range was chosen as it represented a pragmatic and contemporary sample since the widespread introduction of internet based journals. The remaining articles were screened by title and abstract by the primary author (SK). For papers where the full text could not be retrieved, the authors were contacted via Researchgate (www.researchgate.com) or email, or both. Quality of identified papers was assessed using the GRADE criteria [ [ ] ].

\section{Types of publications}

The review included case studies and series published in the English language. Letters, editorials, and literature reviews were excluded.

\section{Types of participants/population}

The patients in the case studies had all experienced an event of swallowing or aspirating a dental prosthesis.

\section{Disease definition}

The case series all described at least one event of either swallowing or aspirating a dental prosthesis.

\section{Inclusion and exclusion criteria}

The full text of all case series of relevance was obtained for assessment against the following inclusion criteria: described at least one case of either swallowing or aspirating a dental prosthesis.

The following exclusion criteria were applied to case series: case series in which data were not presented as a case by case series but were given as overall observations and averages.

\section{Data extraction and data items}

Data were collected using a specially designed data extraction form on: 1) the circumstances of the event, 2) any patient factors identified in the case study which may have contributed to the event, 3 ) the presenting symptoms of the patient, 4) the design of the denture (material, clasps, maxillary or mandibular), 5) the anatomical position at which the denture got lodged, 6) whether the denture caused perforation of the viscus, 7) the procedure required to remove the impacted denture.

Any available photos of the dental prostheses were also collected, and analysed for type of denture, presence of clasps, size of the denture, and material.

\section{Risk of bias assessment}

Assessment of risk of bias was not undertaken, as the studies were descriptive case studies and were not subject to bias within themselves.

\section{Synthesis of results}

Data were collected on a Microsoft Excel spreadsheet (Microsoft, version 14.3), and analysed using statistical package (SPSS, IBM, version 9.2). Associations tested included whether the procedure used to retrieve the denture varied by presence of clasps, whether presence of clasps affected likelihood of spontaneously passing the denture, and thirdly whether dentures with clasps were more likely to cause perforation. Chi-square test was used for statistical data analysis. Significance level was set to 0.05 (Figure 1).

\section{RESULTS}

86 case reports and case series were reviewed [6-91]. In twelve of these the full text could not be retrieved but sufficient information was included in 11 of the abstracts to include in the final analysis. Two of the case series were large, including 47 and 15 patients, $[\underline{7}, \underline{63}]$ and these were not included in the final analysis because of the way the results were presented and the absence of information on denture design. Therefore three further papers were excluded from final analysis $[\underline{7}, \underline{63}, \underline{70}]$.

Therefore 83 case reports and case series which included sufficient information on 91 separate swallowing and aspirating events were identified from 28 countries. From these, there were 49 photos of the swallowed or aspirated dentures. All of the papers were case series and reports, and therefore the quality of evidence was rated as 'very low' throughout. No risk of bias was identified in any of the studies (Table 1).

\section{Patient factors}

The mean age of patients was 55 (SD 16.9) years (range 15 - 93 years), with $74 \%$ male. There was no identifiable causative patient factor in 51 of the patients $(56 \%)$, with no recording of this information in $5(6 \%)$. Of the remaining 35 patients, eight had a stroke, seven had dementia, four had epilepsy, and the rest were split between alcohol or opiate intoxication, learning difficulties, schizophrenia, Parkinson's disease and multiple sclerosis. 


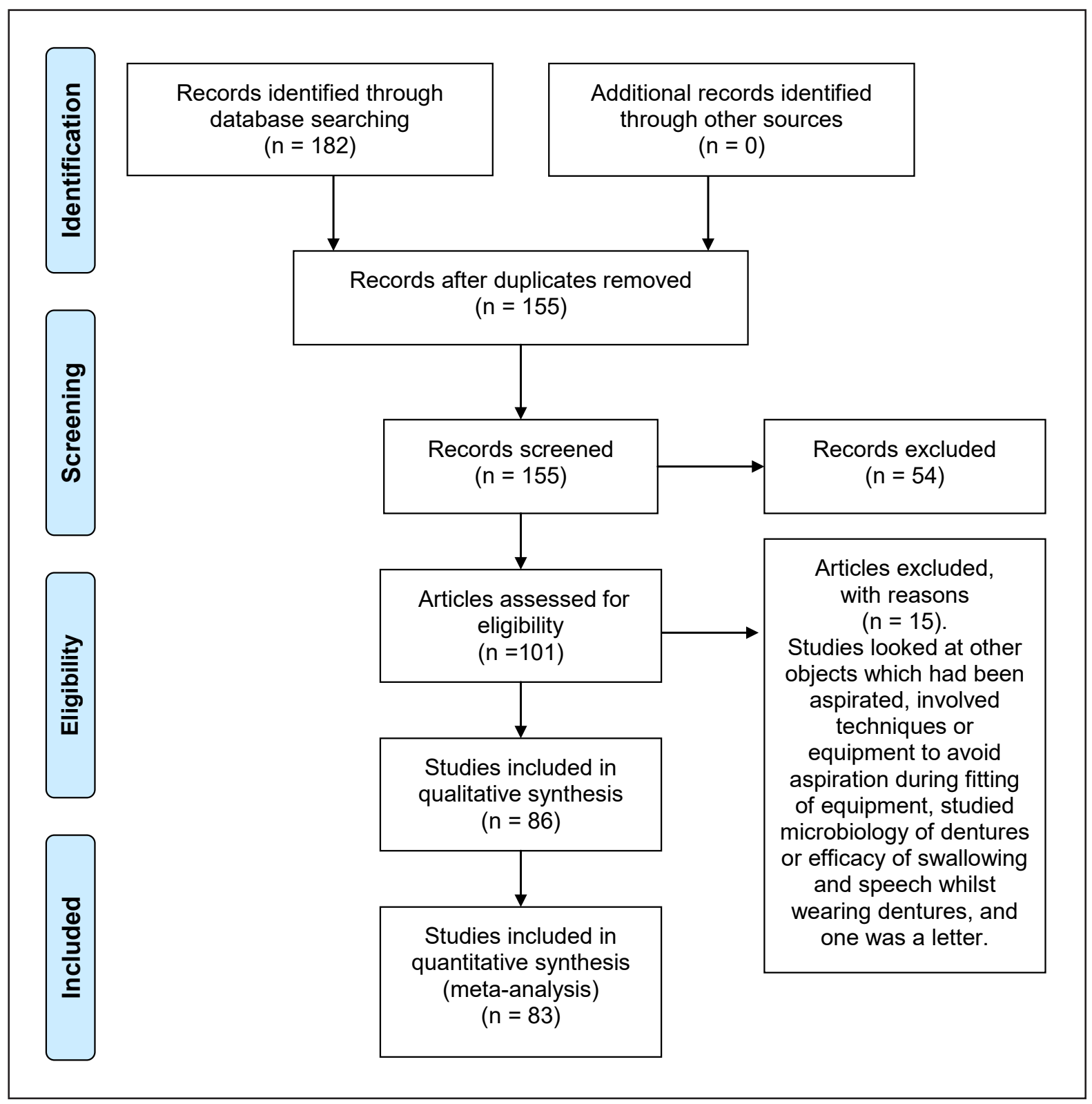

Figure 1. PRISMA flow diagram.

The circumstance of swallowing or aspirating the denture was known in $53(58 \%)$ situations. Of those that were recorded or known, 28 (31\%) were whilst eating, 6 occurred during a general anaesthetic, 5 occurred during trauma (which ranged from a simple fall to a shotgun wound to the face), 4 were whilst sleeping and 4 were during seizures. The remainder occurred whilst intoxicated with alcohol or drugs, whilst fitting the denture or during a stroke. One letter (which was not included in the final analysis as it did not report on denture characteristics, demographics of the wearer, or retrieval method) reported a swallowed denture whilst diving into a swimming pool [92].

\section{Morbidity}

The most common anatomical site for the denture to be lodged was the oesophagus, with 33 in the upper gastrointestinal tract (proximal oesophagus to stomach). Twelve dentures lodged in the hypopharynx or larynx. No differentiation was made between the hypopharynx and larynx as most case reports did not differentiate. Nineteen lodged in the airways (trachea to lungs), seventeen in the middle and lower gastrointestinal tract (ligament of Treitz to rectum) and seven passed through the gastrointestinal tract. In thirteen cases the patient had suffered from a perforation of the gastrointestinal tract, and in two cases a trachea-oesophageal fistula had formed.

The procedures required to retrieve the dentures were split between endoscopic and open procedures. Endoscopic ( $\mathrm{n}=38$ procedures, 42\%) included flexible and rigid bronchoscopies, flexible and rigid oesophagoscopies, gastroscopy and colonoscopy. 
Table 1. Characteristics of included case reports and series

\begin{tabular}{|c|c|c|c|}
\hline \multirow{2}{*}{ Characteristic } & \multirow{2}{*}{ Total } & $\mathbf{N}$ & $\%$ \\
\hline & & 83 & 100 \\
\hline \multirow{16}{*}{ Year of publication } & 2015 & 10 & 12 \\
\hline & 2014 & 9 & 11 \\
\hline & 2013 & 3 & 4 \\
\hline & 2012 & 7 & 8 \\
\hline & 2011 & 6 & 7 \\
\hline & 2010 & 9 & 11 \\
\hline & 2009 & 9 & 11 \\
\hline & 2008 & 8 & 10 \\
\hline & 2007 & 3 & 4 \\
\hline & 2006 & 3 & 4 \\
\hline & 2005 & 4 & 5 \\
\hline & 2004 & 4 & 5 \\
\hline & 2003 & 1 & 1 \\
\hline & 2002 & 3 & 4 \\
\hline & 2001 & 1 & 1 \\
\hline & 2000 & 3 & 4 \\
\hline \multirow{3}{*}{ Number of cases reported } & 1 & 78 & 94 \\
\hline & 2 & 2 & 2 \\
\hline & 3 & 3 & 4 \\
\hline \multirow{8}{*}{ Country } & UK & 15 & 18 \\
\hline & USA & 14 & 17 \\
\hline & India & 11 & 13 \\
\hline & Turkey & 6 & 7 \\
\hline & Japan & 6 & 7 \\
\hline & Brazil & 4 & 5 \\
\hline & Spain & 3 & 4 \\
\hline & Other (21) & 24 & 29 \\
\hline
\end{tabular}

$\mathrm{N}=$ number of studies.

Open procedures $(n=33,36 \%)$ included bowelresection and enterotomy (16), cervical oesophagectomy (8), transthoracic oesophagectomy and bronchotomy (4), tracheostomy (4), and Hartmann's procedure. In three cases the denture was not retrieved due to death and due to 'family wishes' in an elderly man with dementia in India. Procedure was not recorded in 8 cases.

\section{Dentures}

The dentures were divided broadly into fixed $(\mathrm{n}=18$, $20 \%)$ or removable $(\mathrm{n}=60,67 \%)$. Thirty one $(34 \%)$ were maxillary and $21(23 \%)$ mandibular, and it was unclear in $39(43 \%)$ cases. The fixed prostheses were mainly tooth supported bridges, between two and eleven units, with an average of four units. Of the removable prostheses, twenty four $(42 \%)$ were clasped.
Table 2. Description of cases

\begin{tabular}{|c|c|c|c|}
\hline \multirow{2}{*}{ Characteristic } & \multirow{2}{*}{ Total } & $\mathbf{N}$ & $\%$ \\
\hline & & 91 & 100 \\
\hline \multirow{6}{*}{ Age } & $10-29$ years & 4 & 4 \\
\hline & $30-49$ years & 25 & 27 \\
\hline & $50-69$ years & 37 & 41 \\
\hline & 70 - 89 years & 16 & 18 \\
\hline & $>90$ years & 2 & 2 \\
\hline & Not reported & 7 & 8 \\
\hline \multirow{2}{*}{ Gender } & Male & 67 & 74 \\
\hline & Female & 24 & 26 \\
\hline \multirow{5}{*}{$\begin{array}{c}\text { Identified patient fac- } \\
\text { tors }\end{array}$} & None & 51 & 56 \\
\hline & Stroke & 8 & 8 \\
\hline & Dementia & 7 & 8 \\
\hline & Epilepsy & 4 & 4 \\
\hline & Other & 21 & 24 \\
\hline \multirow{7}{*}{ Circumstances of event } & Not known or reported & 38 & 42 \\
\hline & Eating & 28 & 31 \\
\hline & General anaesthetic & 6 & 7 \\
\hline & Trauma & 5 & 5 \\
\hline & Sleeping & 4 & 4 \\
\hline & Seizure & 4 & 4 \\
\hline & Other & 6 & 7 \\
\hline \multirow{6}{*}{ Site of denture } & Airways & 19 & 21 \\
\hline & Hypopharynx or larynx & 12 & 14 \\
\hline & Upper GI tract & 33 & 35 \\
\hline & Lower GI tract & 17 & 19 \\
\hline & Passed spontaneously & 7 & 8 \\
\hline & Not reported & 3 & 3 \\
\hline \multirow{4}{*}{ Procedure } & Endoscopic & 38 & 42 \\
\hline & Open surgery & 33 & 36 \\
\hline & Not required & 12 & 13 \\
\hline & Not reported & 8 & 9 \\
\hline \multirow{3}{*}{ Denture } & Clasped & 25 & 27 \\
\hline & Unclasped & 50 & 55 \\
\hline & Not reported & 16 & 18 \\
\hline
\end{tabular}

$\mathrm{N}=$ number of patients.

The most common material was acrylic $(\mathrm{n}=24$, $27 \%)$, followed by acrylic and metal $(\mathrm{n}=17,19 \%)$. No differentiation was made between cobalt chrome, stainless steel and other alloys.

There was no statistically significant relationship between denture design (clasped vs unclasped) and procedure used for retrieval $(\mathrm{P}=0.13)$, or between denture design and perforation $(\mathrm{P}=0.37)$, or between denture design and spontaneously passing a denture in stool $(\mathrm{P}=0.55)($ Table 2$)$. 


\section{DISCUSSION}

Swallowed and aspirated dentures are responsible for significant morbidity and occasional mortality. With an ageing population and a growing global middle class who can afford and desire tooth replacement, this problem is likely to become more common [93]. Our systematic review examines the epidemiology of publications relating to this issue and identifies common design characteristics.

Limitations of this study include the methodologyby only examining case reports we have missed all of the incidents that were not published. Many of these 'straightforward' situations have been missed in our systematic review, and what we have identified is in fact the 'tip of the iceberg'. Therefore we are likely to have a selection bias for cases which fall out with the norm, be that in terms of the magnitude of intervention required, the time a denture was left undiscovered, or even the circumstances of the event. In the author's own experience, removing a denture endoscopically from the hypopharynx of a clinically stable patient who has some dysphagia and reports swallowing their denture is a relatively unremarkable presentation to the emergency department, and this is supported by Bandopathy's [ [ $]$ case series, in which 43 dentures were removed endoscopically with only one requiring cervical oesophagectomy.

However, by examining the reported cases over the past 15 years we are able to draw some limited conclusions on the seriousness of the problem, and design characteristics which these cases had in common.

Firstly, a common theme running through many of the case reports was the diagnostic uncertainty involved in managing patients with swallowed acrylic dentures. When the patient had no recollection of the event, or was unable to express this to the clinicians, the diagnosis was often not made for days or even, in five patients [7-11], years. This could be easily remedied by making the acrylic used in denture production radio-opaque, or adding a metallic foil strip into the denture. This has been suggested by a number of authors [녀,95], but has never been widely adopted. We conclude that by including radiopaque material in the acrylic, many of the cases of swallowed or aspirated dentures would have been resolved more quickly and with less morbidity.

A second theme identified in the review was that there was no statistically significant difference in perforation rates or requirement for open surgery between clasped and unclasped dentures. It seems logical that metal clasps might act as a 'fish hook' on the epithelium of the aerodigestive tract, and may therefore require surgical removal, and perforate the gastrointestinal tract. Whilst clasped dentures are radiopaque due to the metal components, they are difficult to remove endoscopically, and after initial attempts to do so patients often required a second visit to the operating theatre for an open procedure. However, in the literature we reviewed [6-91] there was no difference in rates of perforation and open surgery, suggesting that where clasps are required to provide better retention their benefits outweigh perceived risks of morbidity.

A third conclusion is that a number of the dentures identified were damaged at the time of the event. Whilst some of these were broken during the incident (e. g. the acrylic fragments cause by the shotgun blast) [13], most were damaged previously but still worn by the patients [14-18]. This highlights the importance of warning patients not to continue to wear dentures which have been damaged or are loose, the importance of adequate, understandable post insertion instructions and regular recall for denture maintenance.

A fourth conclusion of interest was the number $(56 \%)$ of people who did not have any identifiable predisposing factors to swallowing or aspirating a denture. Most of these events occurred during eating. One paper suggested that the method of eating and drinking could have an effect, with a high number of Indian cases attributed to a particular method drinking (pouring liquids into the mouth from a height, to avoid lip contact with the container, seemed likely to dislodge the denture) []]. Whilst dentists may be aware of the importance of providing a suitable dental prosthesis to patients with oropharyngeal incompetence secondary to epilepsy or stroke, the fact that so many of the cases identified involved patients with no risk factors should highlight that this is a problem which could affect anybody wearing a dental prosthesis.

\section{CONCLUSIONS}

The diagnosis of swallowed or aspirated dentures is often difficult to make, and may be simplified by addition of radiopaque material to acrylic components. Secondly, damaged dentures should not be worn as they appear to be aspirated and swallowed more frequently. Thirdly, all patients, regardless of comorbidity, are at risk of aspirating a swallowing a denture, and fourthly that inclusion of clasps does not appear to statistically increase the morbidity caused by the denture. The development of 
a reporting system would assist in identification of cases, and identification of higher risk denture designs.

Further research involving prospective study of large groups of patients after denture fitting, and guidelines in denture design which aim to minimise the risks and mitigate the damage caused by swallowed and aspirated dentures are required.

\section{ACKNOWLEDGMENTS AND DISCLOSURE STATEMENTS}

The authors report no conflict of interest relating to this study. The authors would like to thank the Ear Nose and Throat department at Aberdeen Royal Infirmary for suggesting the review, and Miss Frances Parkinson for her help in organising the data.

\section{REFERENCES}

1. Steele J, O’Sullivan I. Executive summary: adult dental health survey 2009. London: The Health and Social Care Information Centre. 2009. [URL: http://www.hscic.gov.uk/catalogue/PUB01086/adul-dent-heal-surv-summ-them-exec2009-rep2.pdf]

2. Shillingburg HT Jr, Sather DA, Wilson EL Jr, Cain JR, Mitchell DL, Blanco LJ, Kessler JC. Principles of tooth preparations. In: Shillingburg HT Jr, Sather DA, editors. Fundamentals of fixed prosthodontics. 4th ed. Chicago: Quintessence Publishing Co. Ltd.; 2012. p. 131-18.

3. Ellis H. Anatomy of the oesophagus. Surg. 2011 Nov;29(11):537-40. [doi: 10.1016/j.mpsur.2011.08.002]

4. Candia-de la Rosa RF, Candia-García R, Pérez-Martínez MC. Intestinal obstruction due to foreign body in a patient with adenocarcinoma of the colon: case report. Cir Cir. 2010 Jan-Feb;78(1):87-91. [Medline: 20226134]

5. Guyatt GH, Oxman AD, Vist GE, Kunz R, Falck-Ytter Y, Alonso-Coello P, Schünemann HJ; GRADE Working Group. GRADE: an emerging consensus on rating quality of evidence and strength of recommendations. BMJ. 2008 Apr 26;336(7650):924-6. [Medline: 18436948] [PMC free article: 2335261] [doi: 10.1136/bmj.39489.470347.AD]

6. Bandyopadhyay SN, Das S, Das SK, Mandal A. Impacted dentures in the oesophagus. J Laryngol Otol. 2014 May;128(5):468-74. [Medline: 24759356] [doi: 10.1017/S002221511400070X]

7. Khan MAI, Miah MT, Mahbub MS, Ahasan HN, Rahman MA, Khan MA. Unusual precordial pain by impacted denture. J Medicine 2011 Jan; 12(1):58-60. [doi: 10.3329/jom.v12i1.6933]

8. Tanner NT, Gomez M, Silvestri GA. Denture misadventure: an unusual cause of hemoptysis. J Bronchology Interv Pulmonol. 2009 Jul;16(3):216-8. [Medline: 23168559] [doi: 10.1097/LBR.0b013e3181aa1fe0]

9. Yadav SPS, Gulia JS, Gupta R, Hooda A. Missing denture for 15 years. Journal of Bronchology. 2008 Jan;15(3):199-201. [doi: 10.1097/LBR.0b013e3181772d11]

10. Samarasam I, Chandran S, Shukla V, Mathew G. A missing denture's misadventure! Dis Esophagus. 2006;19(1):53-5. [Medline: 16364046] [doi: 10.1111/j.1442-2050.2006.00539.x]

11. Vithalani PD, Maniyar H. An overlooked bronchial foreign body in adult. Indian J Otolaryngol Head Neck Surg. 2005 Oct;57(4):335-7. [Medline: 23120212] [PMC free article: 3451454]

12. Chadwell JB, Mitchell JR, Donnino M, Peterson C, Guentert P, Arnold C, Walsh M. Aspiration of radiolucent dentures in facial trauma: Case report. Ear Nose Throat J. 2010 Dec;89(12):E1. [Medline: 21174264]

13. Gachabayov M, Isaev M, Orujova L, Isaev E, Yaskin E, Neronov D. Swallowed dentures: Two cases and a review. Ann Med Surg (Lond). 2015 Oct 22;4(4):407-13. [Medline: 26635957] [PMC free article: 4637341] [doi: 10.1016/j.amsu.2015.10.008]

14. Aliyali M, Abedi S. A 50-year-old man with progressive dyspnea. Tanaffos. 2012;11(1):61-2. [Medline: 25191403] [PMC free article: 4153181$]$

15. Efeoglu C, Coşkun G. Management issues of a patient who ingested a denture: a case report. Acta Stomatologica Croatica. 2011 Jun; 45(2):131-34. [URL: http://hrcak.srce.hr/69096]

16. Chrcanovic BR, Souza LN. Tracheotomy for a foreign body in the larynx. Oral Maxillofac Surg. 2009 Mar;13(1):55-8. [Medline: 19194730] [doi: 10.1007/s10006-009-0148-6]

17. Sadeghi NR, Alloy A, Masciarelli A. Swallowed teeth. Clin Gastroenterol Hepatol. 2007 Jun;5(6):e22. [Medline: 17544988] [doi: 10.1016/j.cgh.2007.03.023]

18. Boopathy V, Bakshi SS, Balasubramanian P, Dakshinamoorthy S. Neglected partial denture in the lower oesophagus presenting after 7 days. BMJ Case Rep. 2015 Sep 30;2015. [Medline: 26424822] [doi: 10.1136/bcr-2015-211400]

19. Saunders R. Partial denture swallowed by patient with dementia. Spec Care Dentist. 2015 Jun; 35(5):258-60. [Medline: 26084039] [doi: 10.1111/scd.12121]

20. Safdar SA, Shaaban H, Miller RA. Foreign body aspiration. Heart Lung Circ. 2015 Oct;24(10):1033-4. [Medline: 26021970] [doi: 10.1016/j.hlc.2015.03.010]

21. Yip M, Blecher G. ABC: Don't forget to clear the airway! Emerg Med Australas. 2015 Aug;27(4):372-3. [Medline: 26072919] [doi: 10.1111/1742-6723.12419] 
22. Magzoub el TA, Al Ghamdi SA, Dagriri K, Al Fagih A. A delayed spontaneous expulsion of a three teeth bridge after 6 months period of aspiration in the right lung following cardiac surgery. Saudi J Anaesth. 2015 Jul-Sep;9(3):330-1. [Medline: 26240558] [PMC free article: 4478832] [doi: 10.4103/1658-354X.154742]

23. Haghighi M, Shoaei SD. Pharyngeal Aspiration of Complete Upper Denture in 90-Year-Old Man; a Case Report. Emerg (Tehran). 2015 Summer;3(3):117-9. [Medline: 26495397] [PMC free article: 4608337]

24. Ruckert F, Jonescheit J, Kotzor E, Sold M, Henzler T, Horisberger K. False teeth in an apple core: Unusual presentation of a colorectal carcinoma. Int J Surg Case Rep. 2015;8C:18-21. [Medline: 25603486] [PMC free article: 4353945] [doi: 10.1016/j.ijscr.2014.12.035]

25. Slade PM, Larsen MP. Dysphagia, dysphonia and sore throat following cerebral infarction: an unexpected cause. BMJ Case Rep. 2015 Jul 6;2015. [Medline: 26150638] [doi: 10.1136/bcr-2015-210091]

26. Nayyer VN, Macluskey M. An unusual case of a misplaced denture. Oral Surg. 2014 Dec; 7(S1):88-91. [doi: $10.1111 /$ ors.12114]

27. Jamshed N, Madan K, Ekka M, Guleria R. Successful flexible bronchoscopic management of a large-sized aspirated partial denture. BMJ Case Rep. 2014 Mar 20;2014. [Medline: 24654239] [PMC free article: 3962882] [doi: $10.1136 /$ bcr-2013-202371]

28. Prokopakis E, Ioannidis D, Georgopoulos D, Velegrakis G. An aspirated partial denture as a complication in status epilepticus. Intensive Care Med. 2014 Apr;40(4):616-7. [Medline: 24474527] [doi: 10.1007/s00134-013-3206-3]

29. Abe K, Miki A, Okamura T, Shimada K, Yamamoto T, Aiso M, Tanaka A, Kita H, Kuyama Y, Takikawa H. Endoscopic removal of a denture with clasps impacted in the ileocecum. Clin J Gastroenterol. 2014 Dec;7(6):506-9. [Medline: 25425499] [doi: 10.1007/s12328-014-0539-6]

30. Murray MA, Rogan MP, Morgan RK, Linnane SJ. Bronchial dentures as a cause of airway actinomycosis. BMJ Case Rep. 2014 Aug 22;2014. [Medline: 25150232] [doi: 10.1136/bcr-2014-204109]

31. Kim HS, Kim CH, Kim MO, Joa KL, Chung H, Jung HY. Forgotten denture in a hemiplegic patient. Am J Phys Med Rehabil. 2014 Mar;93(3):267-71. [Medline: 24141105] [doi: 10.1097/PHM.0b013e3182a92f2f]

32. Kumar A, Gumaste P, Lam C, Dostal P, Stoopler ET, Schwab EP. An unusual ingestion in an older person: dentures. J Am Geriatr Soc. 2014 Feb;62(2):399-400. [Medline: 24521379] [doi: 10.1111/jgs.12642]

33. Mogi A, Itoh T, Tanaka S, Kuwano H. Rare case of lung abscess caused by a swallowed denture. Ann Thorac Surg. 2014 Apr;97(4):1423-5. [Medline: 24694419] [doi: 10.1016/j.athoracsur.2013.07.081]

34. Lin YC, Hung MH. Repeated obstructive pneumonia and difficult weaning from ventilator caused by hidden aspirated teeth after endotracheal intubation and tracheostomy. Eur J Anaesth. 2013 Jan; 30(51):182-2. [doi: 10.1097/00003643-201306001-00567]

35. Singh P, Singh A, Kant P, Zonunsanga B, Kuka AS. An impacted denture in the oesophagus-an endoscopic or a surgical emergency-a case report. J Clin Diagn Res. 2013 May;7(5):919-20. [Medline: 23814744] [PMC free article: 3681071] [doi: $10.7860 / j \mathrm{jdr} / 2013 / 5337.2976$ ]

36. Upadhyay Y. Swallowed dental bridge causing ileal perforation. Int J Med and Public Health. 2013 May; 3(1):67-8. [doi: 10.4103/2230-8598.109327]

37. Anwuzia-Iwegbu C, Quereshi Y, Walker R, Patel B. Metal impaction: an unusual cause of dysphagia. BMJ Case Rep. 2013 Jun 27;2013. [Medline: 23814218] [PMC free article: 3703064] [doi: 10.1136/bcr-2013-200000]

38. Arnaiz J, Naranjo JM, Cimadevilla B, Arnaiz AM, Arnaiz ME. Denture aspiration within trachea during seizure. J Emerg Med. 2012 Oct;43(4):700-1. [Medline: 21737225] [doi: 10.1016/i.jemermed.2011.05.022]

39. Okugbo SU, Okoro E, Kesieme E. Removal of impacted dentures with polypectomy snare. J Med Biomed Res. 2012 Jun; 11(1):14-9. [URL: http://www.ajol.info/index.php/jmbr/article/view/81348]

40. Gallas M, Blanco M, Martinez-Ares D, Rivo E, García-Fontán E, Cañizares M. Unnoticed swallowing of a unilateral removable partial denture. Gerodontology. 2012 Jun;29(2):e1198-200. [Medline: 22612837] [doi: 10.1111/j.1741-2358.2011.00621.x]

41. Polat AK, Polat AV, Erzurumlu Z, Celenk P. An accidentally ingested mandibular prosthesis was exempt from surgery. Chirurgia (Bucur). 2012 Nov-Dec;107(6):805-8. [Medline: 23294963]

42. Khedkar SA, Chandwani R, Suvarna P. Accidental swallowing of a removable partial denture. Clinical dentistry, Mumbai. 2012 Jan; 22-5.

43. Patel PH, Slesser AA, Idaikkadar P, Kostourou I, Awad RW. Delayed presentation of a small bowel perforation secondary to an ingested denture. JRSM Short Rep. 2012 Sep;3(9):60. [Medline: 23323200] [PMC free article: 3545345] [doi: 10.1258/shorts.2012.012014]

44. Nath DK, Bagchi G, Chandra S, Chandra G, Nath M, Arora V. Management strategies for aspiration of dental prosthesis. Journal of Oral Health \& Research. 2011 Jan;2(1):11-6.

45. Tihan D, Trabulus D, Altunkaya A, Karaca S, Cıhan A, Aliş H. Esophageal perforation due to inadvertent swallowing of a dental prosthesis. Turk J Gastroenterol. 2011 Oct;22(5):529-33. [Medline: 22234762] [doi: 10.4318/tjg.2011.0290]

46. Casap N, Alterman M, Lieberman S, Zeltser R. Enigma of missing teeth in maxillofacial trauma. J Oral Maxillofac Surg. 2011 May;69(5):1421-9. [Medline: 21216067] [doi: 10.1016/j.joms.2010.05.076] 
47. Webster PJ, Peckham-Cooper A, Lansdown M. Small bowel perforation secondary to accidental dental plate ingestion. Int J Surg Case Rep. 2011;2(7):218-20. [Medline: 22096732] [PMC free article: 3199729] [doi: 10.1016/j.ijscr.2011.07.003]

48. Toshima T, Morita M, Sadanaga N, Yoshida R, Yoshinaga K, Saeki H, Kakeji Y, Maehara Y. Surgical removal of a denture with sharp clasps impacted in the cervicothoracic esophagus: report of three cases. Surg Today. 2011 Sep;41(9):1275-9. [Medline: 21874430] [doi: 10.1007/s00595-010-4467-x]

49. Bunni J, Youssef F. Swallowed dental bridge perforating the terminal ileum. South Med J. 2010 Jun;103(6):593-4. [Medline: 20710154] [doi: 10.1097/SMJ.0b013e3181dfd8a0]

50. Chrcanovic BR, Custódio ALN. Swallowed partial denture: a case report and a literature review. Arq Bras Odontol. 2010 Jan; 6(1):19-24. [URL: http://periodicos.pucminas.br/index.php/Arquivobrasileirodontologia/issue/view/122/showToc]

51. Dalvi AN, Thapar VK, Jagtap S, Barve DJ, Savarkar DP, Garle MN, Shukla AP. Thoracoscopic removal of impacted denture: Report of a case with review of literature. J Minim Access Surg. 2010 Oct;6(4):119-21. [Medline: 21120071] [PMC free article: 2992662] [doi: 10.4103/0972-9941.72600]

52. Repanos C, Hughes O, Waldron J. Management of ingested dentures. Emerg Med J. 2010 Sep;27(9):723. [Medline: 20798107] [doi: 10.1136/emj.2008.071761]

53. chumann C, Kropf C, Rüdiger S, Wibmer T, Stoiber KM, Lepper PM. Removal of an aspirated foreign body with a flexible cryoprobe. Respir Care. 2010 Aug;55(8):1097-9. [Medline: 20667159]

54. Campos MS, Nunes FD, Godoy RS, Rodrigues L Jr, Shinohara EH. Removal of a partial denture from the esophagus with the aid of an endoscope. Int J Prosthodont. 2010 Jul-Aug;23(4):339-41. [Medline: 20617222]

55. Delgado-Plasencia L, Manes-Bonet N, Torres Monzón E. Management of foreign body in esophagus with rigid bronchoscopy. Am J Emerg Med. 2010 Jan;28(1):116.e5-6. [Medline: 20006228] [doi: 10.1016/j.ajem.2009.03.020]

56. Lau G, Kulkarni V, Roberts GK, Brock-Utne J. "Where are my teeth?" A case of unnoticed ingestion of a dislodged fixed partial denture. Anesth Analg. 2009 Sep;109(3):836-8. [Medline: 19690255] [doi: 10.1213/ane.0b013e3181ae06c9]

57. Tanrikulu Y, Erel S, Kismet K, Sahin M, Ortac EK, Akkus MA. Accidental swallowing of partial denture: a case report. Cases J. 2009 Dec 21;2:9363. [Medline: 20087445] [PMC free article: 2808324] [doi: 10.1186/1757-1626-2-9363]

58. Mumoli N, Busoni A, Cei M. A swallowed denture. Lancet. 2009 May 30;373(9678):1890. [Medline: 19482215] [doi: 10.1016/S0140-6736(09)60307-X]

59. Imam SZ, Ikram M, Fatimi S, Iqbal M. Cervical esophagotomy for an impacted denture: a case report. Ear Nose Throat J. 2009 Mar;88(3):833-4. [Medline: 19291633 ]

60. Rathore PK, Raj A, Sayal A, Meher R, Gupta B, Girhotra M. Prolonged foreign body impaction in the oesophagus. Singapore Med J. 2009 Feb;50(2):e53-4. [Medline: 19296010]

61. Chiu YH, Lu WH, How CK, Chen JD. Dental bridge aspiration. Resuscitation. 2009 Feb;80(2):157-8. [Medline: 19059691] [doi: 10.1016/j.resuscitation.2008.10.024]

62. Chew TS, Al Ani FS, Hafeez I. Mysterious foreign object on percutaneous endoscopic gastrostomy insertion. Gastroenterology. 2009 Dec;137(6):e9-10. [Medline: 19879988] [doi: 10.1053/j.gastro.2009.04.060]

63. Wadhera R, Gulati SP, Garg A, Ghai A, Kalra V. Clinical experience of removing dentures from aerodigestive tract. J Bronchology Interv Pulmonol. 2009 Jul;16(3):180-2. [Medline: 23168548] [doi: 10.1097/LBR.0b013e3181aec146]

64. Tawari GJ, Kumar S, Hirmiz ZN, Maheshwar A. Denture: an emergency department misadventure. Eur J Emerg Med. 2008 Jun;15(3):176-8. [Medline: 18460962] [doi: 10.1097/MEJ.0b013e3282fb0001]

65. Auluck A, Desai R. Accidental swallowing of a prosthesis. Dent Update. 2008 Oct;35(8):577-9. [Medline: 19055095]

66. Moon SK, Lee JM, Jeong HB, Song JY, Kim SK, Lee SH, Yoon HK, Lee SY, Kim SC, Moon HS. A case of radiolucent foreign body (temporary resin bridge) aspiration accompanied by inflammatory polyps. Tuberc Respir Dis. 2008 Jun;64(6):456-9. [doi: 10.4046/trd.2008.64.6.456]

67. Chen CY, Lee SC, Chen CW, Chen JC. Denture mis-swallowing in the sliding esophageal hiatal hernia mimics esophageal perforation. J Formos Med Assoc. 2008 Aug;107(8):663-6. [Medline: 18678551] [doi: 10.1016/S0929-6646(08)60185-0]

68. Palanivelu C, Rangarajan M, Parthasarathi R, Senthilnathan P. Thoracoscopic retrieval of a "smiling" foreign body from the proximal esophagus: an impacted denture. Surg Laparosc Endosc Percutan Tech. 2008 Jun;18(3):325-8. [Medline: 18574430] [doi: 10.1097/SLE.0b013e3181661919]

69. Yardeni D, Malik AN, Harkin TJ. Iatrogenic swallowing of dentures with resultant tracheal compression requiring mechanical ventilation: a case report. J Bronchol. 2008 Jan; 15(1):67-8. [doi: 10.1097/LBR.0b013e318162eb2f]

70. Nambron R, Pati S, Dharmarajah R. 'Where are my dentures?': risk of denture asphyxia in an elderly patient. Eur J Emerg Med. 2008 Feb;15(1):61-2. [Medline: 18180672] [doi: 10.1097/MEJ.0b013e3282aa41c3]

71. Adhikari P, Neupane Y, Shrestha B, Acharya K, Sinha B, Baskota, D. Impacted denture in the oesophagus: case report and review of literature. The Internet Journal of Otorhinolarynogology 2008;8(2). [URL: http://ispub.com/IJORL/8/2/8363]

72. Rashid F, Simpson J, Ananthakrishnan G, Tierney GM. Swallowed dental bridge causing ileal perforation: a case report. Cases J. 2008 Dec 12;1(1):392. [Medline: 19077287] [PMC free article: 2630321] [doi: 10.1186/1757-1626-1-392]

73. Haidary A, Leider JS, Silbergleit R. Unsuspected swallowing of a partial denture. AJNR Am J Neuroradiol. 2007 Oct;28(9):1734-5. [Medline: 17885231] [doi: 10.3174/ajnr.A0658]

74. Neustein S, Beicke M. Ingestion of a fixed partial denture during general anesthesia. Anesth Prog. 2007 Summer;54(2):50-1. [Medline: 17579503] [PMC free article: 1893093] [doi: 10.2344/0003-3006(2007)54[50:IOAFPD]2.0.CO;2] 
75. Al-Wahadni A, Al Hamad KQ, Al-Tarawneh A. Foreign body ingestion and aspiration in dentistry: a review of the literature and reports of three cases. Dent Update. 2006 Nov;33(9):561-2, 564-6, 569-70. [Medline: 17176743]

76. Gu YC, Yuan JM. [Case report of enterobrosis and diffuse peritonitis caused by a swallowed removable partial denture]. Shanghai Kou Qiang Yi Xue. 2006 Aug;15(4):446-8. Chinese. [Medline: 16955180]

77. Gambert SR. What you don't see may be the problem. Clinical Geriatrics. 2005 May;13(5):12-4. [URL: http://www.consultant360.com/articles/what-you-don-t-see-may-be-problem]

78. Başoglu OK, Buduneli N, Cagirici U, Turhan K, Aysan T. Pulmonary aspiration of a two-unit bridge during a deep sleep. J Oral Rehabil. 2005 Jun;32(6):461-3. [Medline: 15899026] [doi: 10.1111/j.1365-2842.2005.01472.x]

79. Ekanem VJ, Obuekwe ON, Unuigbe A. Death from ingestion of removable partial denture: a case report. Niger Postgrad Med J. 2005 Mar;12(1):65-6. [Medline: 15827602]

80. Calder N, McGuinness R. Swallowed partial dentures. J R Soc Med. 2004 May;97(5):254. [Medline: 15121821] [PMC free article: 1079477 ] [doi: 10.1258/jrsm.97.5.254-a]

81. Furihata M, Tagaya N, Furihata T, Kubota K. Laparoscopic removal of an intragastric foreign body with endoscopic assistance. Surg Laparosc Endosc Percutan Tech. 2004 Aug;14(4):234-7. [Medline: 15472556] [doi: $10.1097 / 01$. sle.0000136682.69871.db]

82. Hashmi S, Walter J, Smith W, Latis S. Swallowed partial dentures. J R Soc Med. 2004 Feb;97(2):72-5. [Medline: 14749401] [PMC free article: 1079292] [doi: 10.1258/jrsm.97.2.72]

83. Ohno S, Miura M, Ichimaru K. [Two cases of denture foreign body in the esophagus in the aged with mental disorder]. Practica Oto-Rhino-Laryngologica. 2004 Oct; 97(11):983-6. Japanese. [doi: 10.5631/jibirin.97.983]

84. Coskun H, Karadag M, Senkaya I, Basut O. Removal of an aspirated denture through a tracheostome. J Bronchol. 2003 Apr; 10(2):129-132. [doi: 10.1097/00128594-200304000-00009]

85. Oghalai JS. Aspiration of a dental appliance in a patient with Alzheimer disease. JAMA. 2002 Nov 27;288(20):2543-4. [Medline: 12444860] [doi: 10.1001/jama.288.20.2543-JLT1127-5-1]

86. von Rahden BH, Feith M, Dittler HJ, Stein HJ. Cervical esophageal perforation with severe mediastinitis due to an impacted dental prosthesis. Dis Esophagus. 2002;15(4):340-4. [Medline: 12472485] [doi: 10.1046/j.1442-2050.2002.00290.x]

87. Klein AM, Schoem SR. Unrecognized aspiration of a dental retainer: a case report. Otolaryngol Head Neck Surg. 2002 Apr;126(4):438-9. [Medline: 11997791] [doi: 10.1067/mhn.2002.123834]

88. Cottrell SG, Hanley JM. Swallowed partial denture: a case report. Gen Dent. 2001 Jul-Aug;49(4):384-5. [Medline: 12016681]

89. Wasson C. Another case of 'awkward teeth' producing a difficult intubation. Anaesthesia. 2000 Sep;55(9):919-20. [Medline: 10947770] [doi: 10.1046/j.1365-2044.2000.01664-14.x]

90. Chetty K, Gallacher S, Sasoon C, Mahute CK. A case of unsuspected denture aspiration. J Bronchol. 2000 Apr;7(2): 188-9. [doi: 10.1097/00128594-200007020-00018]

91. Ghori A, Dorricott NJ, Sanders DS. A lethal ectopic denture: an unusual case of sigmoid perforation due to unnoticed swallowed dental plate. J R Coll Surg Edinb. 1999 Jun;44(3):203-4. [Medline: 10372496]

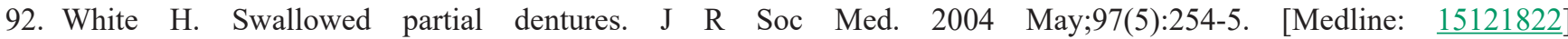
[PMC free article: 1079478 ] [doi: 10.1258/jrsm.97.5.254-b]

93. Thomson WM, Ma S. An ageing population poses dental challenges. Singapore Dent J. 2014 Dec;35C:3-8. [Medline: 25496579] [doi: 10.1016/j.sdj.2014.10.001]

94. Bloodworth KE, Render PJ. Dental acrylic resin radiopacity: literature review and survey of practitioners' attitudes. J Prosthet Dent. 1992 Jan;67(1):121-3. [Medline: 1548595] [doi: 10.1016/0022-3913(92)90061-E]

95. Absi EG, Buckley JG. The location and tracking of swallowed dental appliances: the role of radiology. Dentomaxillofac Radiol. 1995 May;24(2):139-42. [Medline: 9515387] [doi: 10.1259/dmfr.24.2.9515387]

\section{To cite this article:}

Kent SJW, Mackie J, Macfarlane TV.

Designing for Safety: Implications of a Fifteen Year Review of Swallowed and Aspirated Dentures

J Oral Maxillofac Res 2016;7(2):e3

URL: http://www.ejomr.org/JOMR/archives/2016/2/e3/v7n2e3.pdf

doi: $10.5037 /$ jomr.2016.7203 
Copyright (C) Kent SJW, Mackie J, Macfarlane TV. Published in the JOURNAL OF ORAL \& MAXILLOFACIAL RESEARCH (http://www.ejomr.org), 30 June 2016.

This is an open-access article, first published in the JOURNAL OF ORAL \& MAXILLOFACIAL RESEARCH, distributed under the terms of the Creative Commons Attribution-Noncommercial-No Derivative Works 3.0 Unported License, which permits unrestricted non-commercial use, distribution, and reproduction in any medium, provided the original work and is properly cited. The copyright, license information and link to the original publication on (http://www.ejomr.org) must be included. 